\title{
A manera de presentación
}

Nos llena de satisfacción presentar este número 12 de la Revista de Museología Kóot, sobre todo porque a pesar de la amenaza que vive el planeta a través de la pandemia de Covid 19, nos es posible llegar a nuestros queridos lectores a través de Internet o como medio impreso.

Kóot, indexada en Latindex, llega a los rincones más distantes del mundo gracias a las autopistas digitales y los buscadores especializados de Google. Tenemos constancia, gracias a correspondencia, invitaciones a conferencias y congresos llegados a nuestra redacción, de instituciones científicas y de académicos que siguen nuestro trabajo en países tan disímiles como China, Italia, España, México, Estados Unidos, Argentina y por supuesto El Salvador.

Nuestra Revista especializada llena un vacío y una carencia que existe no solo a nivel nacional sino a nivel internacional, en un mundo en desarrollo donde la museografía ha tomado protagonismo como punto de referencia histórica, antropológica, arqueológica, sociológica, presente con museos temáticos en todas las megalópolis y urbes del planeta.

Por ello nos es grato presentar la gama de artículos científicos que componen el presente número y que van desde el atinado trabajo filosófico del Dr. Eduardo Badía Serra acerca del libro de Stephen Hawking, "Breves respuestas a las grandes preguntas".

Doctor en filosofía y catedrático de filosofía y ética en la Universidad Tecnológica de El Salvador, Rubén Fúnez nos presenta su artículo titulado "Estructura de una broma", un tema poco común pero no menos importante, ya que se busca demostrar las consecuencias que se desprenden de una broma y quiénes son las personas que gustan de hacer este tipo de acciones en la sociedad.

Kóot como un órgano oficial de la Universidad Tecnológica de El Salvador es una revista con un espíritu democrático, abierta a los diferentes puntos de vista de la museografía y la cultura en general y el único requisito que exigimos a nuestros colaboradores es el criterio de calidad y ética que conlleva redactar un ensayo científico. Por ello Kóot constituye un instrumento académico de 
difusión especializada tanto en el ámbito universitario como en los ámbitos especializados de la multidisciplinaridad científica.

Tal como lo dejo plasmado en su importante novela el Premio Nobel guatemalteco Miguel Ángel Asturias, "Hombres de maíz", esta gramínea es parte consustancial de la idiosincrasia y la identidad mesoamericana, elevándola incluso al carácter de mito fundacional y deidad del panteón de los pueblos precolombinos mayenses y nahuas que poblaron nuestras tierras. Por ello me permito presentarles en las páginas de este número mi ensayo intitulado "El Maíz, fuente de cultura mesoamericana", donde encontraran un recuento del vital significado e importancia del maíz que va desde lo más elemental de nuestra cotidianeidad, como el hecho de que la tortilla está presente todos los días tanto en la casa del rico como del pobre, hasta en los niveles religiosos y antropológicos de esta planta de primera necesidad en nuestro país y nuestra región.

Se incluyen los artículos del Dr. Jaime Alberto López Nuila, "El Arte Taíno", en donde se describe de forma somera el quehacer social y cultural de los pueblos Taínos; "El predominio intelectual de los mulatos a fines de la dominación colonial hispana", del Embajador de la República Dominicana en la República en El Salvador, Fernando Pérez Memén.

En esta misma línea se inscribe el ensayo histórico antropológico del Licenciado en Filosofía por la Regina Apostolorum de Roma, Reynaldo Antonio Rivas "Los historiantes de Huertas: La danza de los Moros y Cristianos".

Que disfruten esta entrega de nuestra revista que se engrandece cada día gracias a sus fieles y sabios lectores.

\author{
Dr. Ramón D. Rivas \\ Director de Cultura \\ MUA
}


